\title{
High Performance Work Systems and Organizational Performance of Sales Representatives of Pharmaceutical Companies in Chiclayo
}

\author{
Diego Alejandro Ludeña Jugo \\ Universidad Católica Santo Toribio de Mogrovejo \\ Marco Agustín Arbulú Ballesteros \\ Universidad Tecnológica del Perú
}

\begin{abstract}
The purpose of the study has been to differentiate the importance of the high-performance work systems (HPWS) effects, for dimensions, in the performance of sales representatives of pharmaceutical companies in Chiclayo having affective commitment and human capital as mediation variables. HPWS have a significant effect on development through human capital, but not with affective commitment. However, there are HPWS' subdimensions that affect development through the "motivational path" (training, performance assessment and empowerment practices) which also affect in a considerable way through human capital. An activity that also affects performance through human capital significantly is the compensations and incentives one.
\end{abstract}

Keywords: high-performance work systems, affective commitment, human capital, performance, pharmaceutical industry 


\section{Sistemas de Trabajo de Alto Desempeño y Desempeño Organizacional de Representantes de Ventas de Empresas Farmacéuticas en Chiclayo}

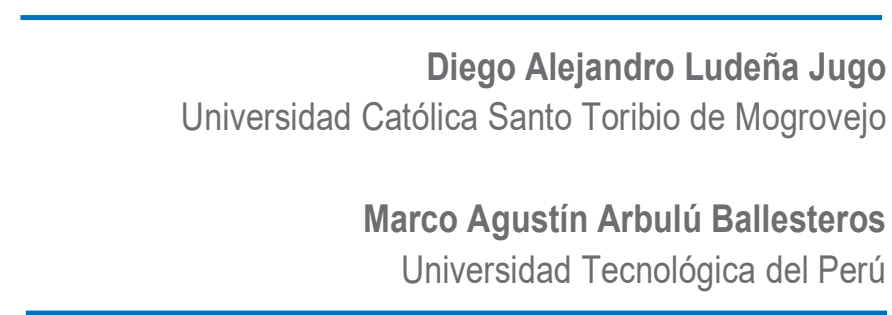

\section{Resumen}

El propósito del estudio ha sido diferenciar la importancia de los efectos de los sistemas de trabajo de alto rendimiento (HPWS), por dimensiones, en el desempeño de los representantes de ventas de empresas farmacéuticas de Chiclayo teniendo como variables mediadoras el compromiso afectivo y el capital humano. HPWS tiene un efecto significativo en el desarrollo a través del capital humano, pero no con compromiso afectivo. Sin embargo, existen subdimensiones de HPWS que inciden en el desarrollo a través del "camino motivacional" (prácticas de capacitación, evaluación del desempeño y empoderamiento) que también inciden de manera considerable a través del capital humano. Una actividad que también afecta significativamente el desempeño a través del capital humano es la de compensaciones e incentivos. 


\section{Introduction}

The activities of the human talent area, known as high-performance work systems (HPWS), have a decisive impact on organizational performance, which is associated with the purposes of the company (Huselid, 1995; Combs, Liu, Hall, \& Ketchen, 2006; Combs, Liu, Hall, \& Ketchen, 2006).

Sales representatives of pharmaceutical companies in Chiclayo face little support from the people involved with the human talent teams, who work in the city of Lima, where the company's activities are centralized. The training received by sales representatives is scarce, as are the forms of motivation. There is also a noticeable imbalance between the treatment received by those working in Lima and that given to sales representatives in the capital city. This situation is expressed by a sales team leader of a pharmaceutical company in Chiclayo (personal communication, October 29, 2019).

There are HPWS in Peruvian pharmaceutical companies and these have an effect on sales teams; however, the lack of proximity to sales representatives in Chiclayo is an aspect that could lead to a detriment of their skills and involvement, in addition to diminishing the contribution of each representative in this city.

Those who work with the human area are called to give a favorable treatment to the people involved with the work concerning the company. Involvement and training make up the responsibility of this team. There are multinational companies that can be considered as examples to explain this idea (Muntean, 2014).

It is necessary to understand the size of the effect of HPWS activities to the contribution made by the people involved with them, through their mood and capabilities. Raineri (2017), with his work, explained that there are actions, such as compensation and incentives, that affect performance only through a mediator, such as motivation (affective commitment) and not with the other, case with human capital. The author also argued that the HPWS-performance causality, previously studied in countries such as Finland and China, can also be generalized to Latin American contexts.

The essence of the work is embodied in a broader understanding of the contribution of the activities of the human talent areas of companies to the achievement of their purposes, being this a recent topic and little covered in the last 12 years. With this, the study can be a support so that those who make decisions with human talent areas of companies -differing from the types of companies they work with- can recognize the effects of their actions and improve or reorient their activity in favor of the people involved with the company. This implies that there may be improvements in the contributions of teams, not only from sales, but also from those who carry out other activities.

If people receive constant social and technical training and have acquired trust with the work team, they have the possibility of contributing not only to a company, but also to other social groups, in addition to being able to spread a close relationship. In this way, there can be a benefit to society.

\section{Literature Review}

A study in Chile was conducted to recognize the effect of HPWS on human capital and affective commitment as mediators in affecting performance. A multiple mediation analysis was carried out, which serves to prove that perceptions about HPWS practices by people working with Chilean companies are predictors of work group performance, considering the mediation of human capital and affective commitment. The information found alludes that there are practices 
that only affect motivation (affective commitment) and not human capital, such as compensation and incentives (Raineri, 2017).

A meta-analysis was conducted by representatives of an American and a French university to analyze the effects of the 3 sub-aspects or dimensions that comprise the HPWS (explained under title 2.2 of this paper) on what are known as "organizational outcomes", through human capital and motivation. They considered works published with electronic platforms, and facilitated with support from organizations associated with business, psychology and human talent; and structural equations to recognize, in a partial way, the proposed causalities (Jiang, et al., 2012).

A theoretical analysis was done by representatives of New Zealand universities. The purpose was to clarify the explanation of HPWS and to distinguish terms that seem analogous, such as "high involvement work systems". The authors support the idea that the involvement perspective supports the understanding of HPWS; and that, if business representatives consider that people should be involved with the work and the business, their perceptions of what managers have done about it should be acknowledged before arranging for changes (Boxall and Macky, 2009).

A study was made with multinational companies in the United States, Finland and Russia, with the purpose of recognizing the scope of the effects of the activities of the human talent areas on the performance in each country, considering the forms of causalities. The authors used Likert scales to recognize the aspects they addressed and a partial least squares method; with the information they found, the proposed explanations are supported, except for the one that skills are associated with performance, and distinctions with companies in different countries (Fey, Morgulis-Yakushev, Park \& Björkman, 2009).

Another previous research was done with companies in China to understand the perceptions of HPWS by people involved in business transformation; surveys and methods such as correlation and hierarchical regression were carried out; which led to explain the effect of HPWS on "organizational commitment"; as well as it was found that aspects such as gender and marital status are related to the mentioned effect (Qiao, Khilji \& Wang, 2009).

A previous research in Japan was carried out with the purpose of understanding the effect of HPWS on organizational effectiveness, considering collective human capital and social exchange as mediating variables. The authors conducted surveys with companies of various types and analyzed the information obtained with hierarchical and path regression analysis; with that, they were able to support that there are mediated and not immediate effects; rather, that the direct effect of HPWS on effectiveness is not significant. This is one of the first empirical investigations on this causality (Takeuchi, Lepak, Wang and Takeuchi, 2007).

Another theoretical analysis was carried out by a representative of a university in Holland; the aspects covered are work motivation and performance, considering social identity. The author explains that identification is associated with the concepts known as those of motivation and performance, considering two types of the latter: that of the activity itself - concerning the work - and the contextual - referring to a behavior that affects social and psychological circumstances of work (van Knippenberg, 2000).

Theoretical-scientific basis

Performance.

Ilies and Metz (2017) conduct a review of explanations on the subject. Performance is considered an effect of work, which is associated with the company's purposes, customer experience and profits. 


\section{Perceived organizational performance.}

There may be inconveniences in seeking information about job performance (Dess \& Robinson, 1984). Because of suspicion or the difficulty of recognizing similarities between them, it can be difficult to obtain data. To deal with this situation, an alternative is to work with perceptual information from individuals. There is a closeness of reliability between this information and objective information, as found by the authors cited at the beginning of this paragraph.

High Performance Work Systems (HPWS).

Bailey and Merrit (cited in Chow, 2004) refer to the concept of HPWS as a work scheme that allows people to be involved in company decisions and the work of the human resources area, whose responsibility is to train people's skills and give them incentives so that their participation with the team has a favorable effect.

Skill, Motivation and Opportunity Model (HMO).

Appelbaum, Bailey, Berg, and Kalleberg (cited in Raineri, 2017) propose that HPWS are comprised of different groups of activities in the human area that lead people to perform better. The authors mentioned at the beginning of this paragraph propose a classification called the HMO model (AMO: abilities, motivation and opportunities), which comprises groups or dimensions whose names correspond to the acronyms of this classification of improvement activities:

the skills development activities, which are made up of personnel selection, job description, performance evaluation and training, are considered as activities that lead people to develop the skills to carry out the following activities: - training and development of skills, which are made up of personnel selection, job description, performance evaluation and training;

motivation, which includes compensation and incentives, practices that make a person willing to take on responsibilities; and

opportunities, which include the participation and involvement of people in the company's decisions, freedom to make decisions, facilities to contribute improvements, communication with team representatives, fairness and reasonableness of the ways in which people can complain, as well as teamwork and empowerment, which encourage people to have better possibilities to respond to different situations.

Human resources activities.

Selection of people: the search for people to carry out a job with the company. Prior to this, those who carry out the activities of the human area make a recognition of the responsibilities and skills needed for that job, known as job analysis (Mathis \& Jackson, 2008).

Performance evaluation and training: the authors cited at the beginning of this list mention that it is the verification of people's work and the preparation that company representatives give them to carry out different activities and face different situations. It is part of the aspect called talent management and development.

Job description: considering the same reference, the manifestation of the activities, capabilities, skills and knowledge necessary to carry out a job, alluding to what is mentioned by the authors cited with the first activity mentioned. To carry out this, it is necessary to have previously recognized what they are, with the activity known as job analysis.

Compensations and incentives: referred to as "rewards" by the authors themselves; they are the payments, bonuses, benefits, incentives that people receive for carrying out their work. It is the responsibility of the company's representatives to improve them. They include aspects such as variable payments and health benefits. 
Empowerment practices: these are activities that allow people to contribute their skills to the team (Lepak, Liao, Chung, \& Harden, 2006).

Mediating variables.

Affective commitment.

Buchanan (1974) mentions that commitment is referred to as the affective rapport with the purposes and values of an organization, to the person's role in relation to its purposes and values, and to the organization for its own benefit, apart from the instrumental value (of the organization's).

On the basis of definitions such as the above, Meyer and Allen (1984) used the term indicated with this title.

Human capital.

Although it is obvious that people acquire useful skills and knowledge, that these are a form of capital is not; they are, in substantial part, a product of deliberate investment. From this, the concept of human capital is deductible. This is an explanation that is still valid (Schultz, 1961).

Instruments for obtaining information.

The means have been adapted by Raineri (2017), who has considered the use of questionnaires, of which, the major parts of elements, are from and adapted from instruments by Sun, Aryee, Law (2007); Wright, Garden, Moynihan (2003); Allen and Meyer (1990); Delaney and Huselid (1996); Subramaniam and Youndt (2005).

About performance.

A perceptual test is adapted from the work of Delaney and Huselid (1996) by Raineri (see Annex A4); it contemplates 5 statements. These allow the respondents' perceptions of the progress or performance of the work team with which they are involved in the last year to be recognized. The statements translate or disaggregate this performance into quality of products and/or services, progress or productivity of the work team, customer satisfaction, creation or development of new products and/or services and treatment or relations between the representative and those involved in the team.

People are instructed to recognize the progress of the groups, considering as a reference those of similar teams of similar companies in the last year. A Likert scale between 1 (worse) and 6 (much better) is used.

About HPWS.

To recognize this aspect, in Annex A1, there is a 24-item scale adapted by Raineri (2017) from Sun et al. (2007) and Wright et al. (2003). The statements are generic, i.e., those who carry out different work with different types of companies can respond to these.

Before the statements, there is an indication that each one describes activities or practices - by the human talent area - that can be carried out to guide the people involved with a company; for example, regarding training, there is an allusion to the frequency with which people receive training; and regarding empowerment, there is a mention of the involvement of people by those responsible for the teams, with decisions.

Then there is an instruction to indicate, with a number, a degree that represents their agreement or disagreement about whether the practice has been carried out with the organization they work with to guide the team they represent in the last 3 years. 
The author considers a 7-point Likert scale: 1 represents total disagreement; and 7, full agreement.

About the affective commitment.

The questionnaire is in Annex A2. This instrument covers 4 items of the affective organizational commitment subscale of Allen and Meyer (1990), such as contentment with work and the personal meaning of this for the respondent. Raineri (2017) uses a 7-point Likert scale, with 1 representing total disagreement and 7, complete agreement.

About human capital.

Subramaniam and Youndt (2005) propose 2 statements from Raineri's (2017) questionnaire, which is in Annex A3. The method consists of sales representatives recognizing the skills and knowledge of the team - each one, with a statement - with reference of those who work with similar teams from analogous companies. The answers are divided on a Likert scale between 1 (worst) and 6 (much better).

About the relevance of the effects between aspects or variables.

It is necessary to recognize the significance of the effects before understanding their relevance. Multiple mediation regressions are considered. These are carried out with the averages of the scores of the mentioned questionnaires, considering aspects, variables and subdimensions, with this work.

The effects analyzed are indirect (considering mediations), direct (without mediations) and total (contemplating the 2 previous ones); the idea is proposed by Hayes (2013a).

When using these regressions, significance coefficients, also known as p-values or probability coefficients, are obtained, which allow omitting the null statistical hypothesis that the predictor is not associated with the aspect or dependent variable $(\mathrm{H} 0: \mathrm{Tb}=0 ; \mathrm{T}$ is a true value and $\beta$ is a regression coefficient), if they are less than or equal to .05; or the alternative - opposite to the null $(\mathrm{H} 0: \mathrm{Tb} \neq 0)$. These values are considered with the unmediated effects, suggests the author mentioned in the previous paragraph.

The significance of the mediated effects is verified with confidence intervals, considering $95 \%$ as the level. Lower and upper bound coefficients are obtained, which represent the possible values for the analyzed effects. If the intervals do not include zero values, the causality is significant.

The standardized $\beta$ s values, also known as betas, represent relevance of causalities. There are no minimum or maximum values that allow explaining relevant effects, being these used to differentiate causalities, considering diverse predictors and mediators (Pardo \& Ruiz, 2005).

Figure 1 represents the causalities, considering the aspects referred to under the generic heading.

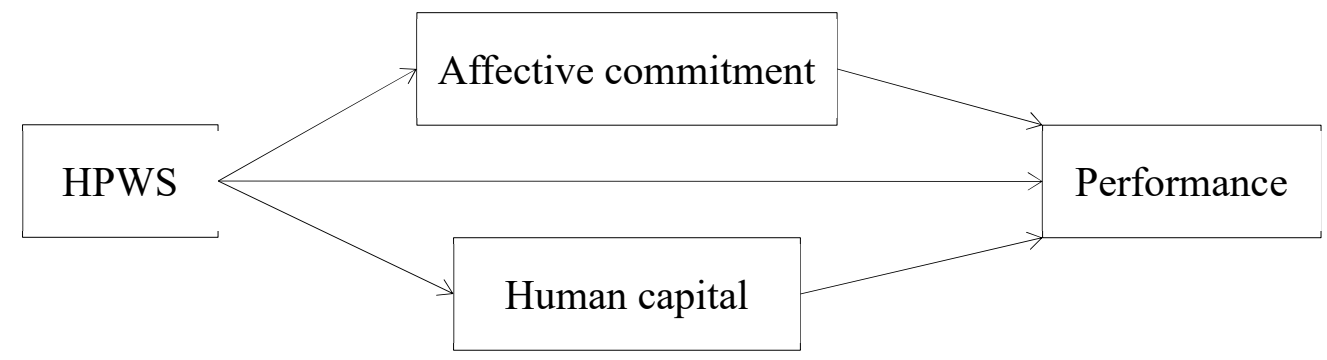


Figure 1. Conceptual schematic of direct effects of HPWS to performance, and indirect effects with affective commitment and human capital. Adapted from "Linking human resources practices with performance: the simultaneous mediation of collective affective commitment and human capital," by A. Raineri, 2017, The International Journal of Human Resource Management, 28, p. 3158. Copyright 2016 by Informa UK Limited, como Taylor \& Francis Group.

\section{Hypothesis}

$H_{1}$ : the most relevant indirect effect of the skill enhancement dimension of HPWS on sales rep performance is through human capital,

$\mathrm{H}_{2}$ : the most relevant mediated effect of the motivation improvement dimension, is through affective commitment and

$H_{3}$ : the most relevant indirect causality in the dimension of improvement of opportunities also occurs with affective commitment as a mediating variable.

\section{Methodology}

\section{Population, sample and sampling}

The population was the sales representatives of pharmaceutical companies in Chiclayo between the months of October 2019 and January 2020, who have at least 1 year of work with the companies they represent. 88 people are contemplated as the total group.

The calculation of the number of people who make up the representative group - known as the sample size - can be considered with reference to an expected percentage. There is a suggestion that the figure should be close to $60 \%$, which alludes to a representative number of people (Fincham, 2008). Of the 88 representatives, 53 were surveyed, with a considerable number of respondents, representing $60.23 \%$.

\section{Results}

\section{Normality}

With the Kolmogorov-Smirnov test, the $\mathrm{p}$ or significance coefficients did not allow us to recognize that the distribution of the data is normal. The one referring to HPWS was $.031 ; .000$ with affective commitment; the same with human capital; and .019 has been the value alluding to performance. The work is non-parametric, the information is consistent with that. The risk of error with data of this type has been addressed with the technique known as bootstrapping.

\section{Reliability}

The Cronbach's alpha coefficient of the HPWS questionnaire was .855 , the value for the affective commitment questionnaire is .924; the human capital scale is reliable at .812 and the group of statements concerning performance is also reliable at .708. The data confirm that the questionnaires are reliable. 


\section{Effects of the skill enhancement activities dimension}

Training and performance evaluations contribute to the mediation with affective commitment in a significant way since the confidence intervals concerning this causality do not include the value 0 . This considerably affects the causality with the dimension to be significant.

The direct effects of the skill improvement activities are considerable, with the largest being that of the job description, due to its coefficient $\beta$, shown in Table 1 . Considering total effects, the aforementioned activity is associated with a broader causality than training and performance evaluations. Although smaller regression coefficients were obtained with these two activities, they still represent explanations that are worthwhile.

Table 1. Statistical values obtained considering the multiple mediation regression analysis and the skill enhancement activities dimension as a predictor aspect

\begin{tabular}{|c|c|c|c|c|c|}
\hline \multicolumn{2}{|c|}{ Effects and coefficients $\backslash$ Aspects } & \multirow{2}{*}{$\begin{array}{c}\begin{array}{c}\text { Selection } \\
\text { of } \\
\text { persons }\end{array} \\
-, 069^{\text {n.s. }}\end{array}$} & \multirow{2}{*}{ 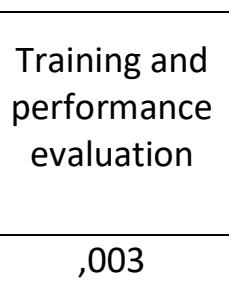 } & \multirow{2}{*}{$\begin{array}{c}\text { Job } \\
\begin{array}{c}\text { descripti } \\
\text { on }\end{array} \\
-, 003^{\text {n.s. }}\end{array}$} & \multirow{2}{*}{$\begin{array}{c}\begin{array}{c}\text { Analysis } \\
\text { of the } \\
\text { dimensio } \\
\mathrm{n}\end{array} \\
, 001\end{array}$} \\
\hline & LLII of IIC at $95 \%$ & & & & \\
\hline of affective & LLSS of IIC at $95 \%$ & 174 & 257 & ,250 & ,263 \\
\hline 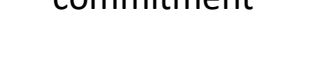 & ßs & ,025 & 081 & ,091 & ,078 \\
\hline \multirow{3}{*}{$\begin{array}{l}\text { indirectly, through } \\
\text { human capital }\end{array}$} & LLII of IIC at $95 \%$ &,$- 082^{\text {n.s. }}$ &,$- 039^{\text {n. s. }}$ &,$- 050^{\text {n. s. }}$ &,$- 052^{\text {n.s. }}$ \\
\hline & LLSS of IIC at $95 \%$ & ,080 & 141 & 115 & 127 \\
\hline & ßs & ,002 & ,028 & 019 & ,022 \\
\hline \multirow{2}{*}{$\begin{array}{c}\text { direct (to } \\
\text { performance) }\end{array}$} & Ps &, $170^{\text {n. s. }}$ & ,044 & ,004 & 015 \\
\hline & ßs & 075 & 151 & ,217 & ,205 \\
\hline \multirow{2}{*}{$\begin{array}{l}\text { total (considering } \\
\text { direct and indirect) }\end{array}$} & $P s$ & $185^{\text {n. s. }}$ & ,012 & ,001 & 005 \\
\hline & ßs & 088 & 221 & 287 & 278 \\
\hline
\end{tabular}

Notes: LLII: lower limits; LLSS: upper limits; IIC: confidence intervals; ${ }^{\text {n.s. }}$ not significant, implying consideration of the $H_{0}$.

\section{Effects of the motivational enhancement activity dimension}

Mediation with human capital leads to significant total causality, but not with affective commitment. This can be understood with the confidence intervals obtained, which are in Table 2. The $p$-value for the direct effect did not allow us to recognize significance. 
Table 2 Statistical values obtained considering the multiple mediation regression analysis and the motivation-enhancing activities dimension as a predictor aspect

\begin{tabular}{|c|c|c|}
\hline \multicolumn{2}{|c|}{ Effects and coefficients $\backslash$ Aspects } & $\begin{array}{l}\text { Compensation and } \\
\text { incentives }\end{array}$ \\
\hline \multirow{3}{*}{$\begin{array}{l}\text { indirectly, through affective } \\
\text { commitment }\end{array}$} & LI of IIC at $95 \%$ &,$- 030^{\text {n. s. }}$ \\
\hline & LS of IIC at $95 \%$ & ,407 \\
\hline & $\beta$ & 152 \\
\hline \multirow{3}{*}{ indirect, through human capital } & LI of IIC at $95 \%$ & ,008 \\
\hline & LS of IIC at $95 \%$ & 239, \\
\hline & $\beta$ & ,079 \\
\hline \multirow{4}{*}{ direct (performance) } & $P$ &, $063^{\text {n.s. }}$ \\
\hline & LI of IIC at $95 \%$ &,- 005 \\
\hline & LS of IIC at $95 \%$ & 187 \\
\hline & $\beta$ & 091 \\
\hline \multirow{2}{*}{$\begin{array}{l}\text { total (considering direct and } \\
\text { indirect) }\end{array}$} & $P$ & ,000 \\
\hline & $\beta$ & 175 \\
\hline
\end{tabular}

Notes: LI: lower limit; LS: upper limit; IIC: confidence intervals; ${ }^{\text {n.s.: }}$ not significant, implies the consideration of the $H_{0}$.

\section{Effects of the opportunity-enhancing activities dimension}

All the effects alluding to this classification are significant, considering the data in Table 3 . The most relevant is the direct one; and, of the indirect ones, the one mediated through affective commitment.

Table 3 Statistical values obtained considering the multiple mediation regression analysis and the dimension of opportunity improvement activities as a predictor aspect

\begin{tabular}{llc}
\hline \multicolumn{2}{c}{ Effects and coefficients $\backslash$ Aspects } & $\begin{array}{c}\text { Empowerment } \\
\text { practices }\end{array}$ \\
\hline $\begin{array}{c}\text { indirectly, through affective } \\
\text { commitment }\end{array}$ & LI of IIC at $95 \%$ &, 001 \\
& $\beta$ &, 316 \\
indirect, through human capital $95 \%$ & LI of IIC at $95 \%$ &, 002 \\
& LS of IIC at $95 \%$ &, 192
\end{tabular}




\begin{tabular}{ccc} 
& $\beta$ &, 025 \\
\hline direct (performance) & $P$ &, 013 \\
& $\beta$ &, 130 \\
\hline $\begin{array}{c}\text { total (considering direct and } \\
\text { indirect) }\end{array}$ & $P$ &, 000 \\
& $\beta$ &, 205
\end{tabular}

Notes: LI: lower limit; LS: upper limit; IIC: confidence intervals.

\section{Effects of HPWS}

The indirect effect with affective commitment is not significant, considering the limit values of the confidence intervals in Table 4; the direct effect is representative in a broader way than that mediated with human capital, although the latter mentioned is still noteworthy. Both lead to a total causality that has been represented with an $R^{2}$ of $28.9 \%$, as shown in the table in Annex B.

Table 4 Statistical values obtained considering multiple mediation regression analysis and the HPWS

\begin{tabular}{|c|c|c|}
\hline Effects & \multicolumn{2}{|c|}{ Coefficients } \\
\hline \multirow{3}{*}{$\begin{array}{l}\text { indirectly, through affective } \\
\text { commitment }\end{array}$} & LI of IIC at $95 \%$ &,$- 028^{\text {n. s. }}$ \\
\hline & LS of IIC at $95 \%$ & ,319 \\
\hline & $\beta$ & 113 \\
\hline \multirow{3}{*}{ indirect, through human capital } & LI of IIC at $95 \%$ & ,002 \\
\hline & LS of IIC at $95 \%$ & 181 \\
\hline & $\beta$ & ,062 \\
\hline \multirow{2}{*}{ direct (performance) } & $P$ & ,004 \\
\hline & $\beta$ & ,230 \\
\hline \multirow{2}{*}{$\begin{array}{c}\text { total (considering direct and } \\
\text { indirect) }\end{array}$} & $P$ & ,000 \\
\hline & $\beta$ & ,341 \\
\hline
\end{tabular}

Notes: LI: lower limit; LS: upper limit; IIC: confidence intervals; ${ }^{\text {n.s.: }}$ not significant, implies the consideration of the $H_{0}$.

\section{Discussion}

On $H_{1}$, it is not expected that training and performance appraisals affect performance through affective commitment in a significant way and that this does not occur with human capital, contemplating that, theoretically, performance appraisals are activities aimed at improving people's skills (Appelbaum et al., cited in Raineri, 2017). 
Although the job description does not lead to a redeemable indirect effect, its direct effect is representative, suggesting that the population considers it necessary for there to be clarity about the activities and responsibilities that their job entails in order to provide input; even the short-term purposes of the company could be considered relevant.

The fact that training and evaluations do not have a significant effect on performance through human capital can be understood through the problems described at the beginning of this article.

This is a disadvantage for medical representatives, as they do not have the necessary guidance to do their job. Possibly, there are those who need to train on their own or look to their superior for guidance. However, this is not the responsibility of either of these two people; it is the responsibility of the human talent area.

There is also the situation of those who already have experience as sales representatives in pharmaceutical companies; they do not need to receive as extensive training as those who are just starting out in the field, although this does not imply that they do not need any guidance or feedback about their work; there may be guidance to learn from the sales representatives.

The performance evaluation may not be such a complex issue, considering that the average scores for this activity have been close to the maximum (out of 7), the lowest average was the scores for the statement alluding to the long-term emphasis on the advancement of people with the reviews.

Ergo, that the representatives of the human talent area evaluate the sales representatives does not guarantee that these can assume greater responsibilities or of their inclination in time; or their continuity with the company, being able to interpret that this activity is carried out, for example, for the calculation of incentives, which is coherent with the average of the scores referring to the salary increases for work contributions and individual incentives.

Therefore, it is coherent that training and performance evaluations have a significant, indirect effect on performance with affective commitment as a mediator, and not with human capital.

It is noteworthy that the job description is directly and significantly related to performance. A possible explanation is that people look for details about their roles in order to make accurate contributions; such information is pertinent to provide before the person is selected.

There is a difference with Raineri (2017), considering that the information obtained with this one allows understanding that the referred skills improvement activities affect significantly through affective commitment and human capital; being the first mentioned, the aspect that has a greater relevance. The direct effects included in this work are significant for the 3 activities mentioned above.

The similarity with this author is that the scope of causality with training and performance evaluations, mediated by affective commitment, is similar to that recognized with the work in Chile; and that there are representations of mediated and immediate effects, as there are significant direct causalities and through affective commitment or human capital; with this last aspect or variable, the data shown by the author of the work in Chile have allowed us to recognize this, which did not occur with this work.

Starting with the data associated with $\mathrm{H}_{2}$, which are shown in Table 8, i.e., compensation and incentives, these only affect human capital in a relevant way.

It can be inferred that, if a person receives larger amounts for his or her activity, he or she pays for job-related training or to move up in the current pharmaceutical company or others. 
Theoretically, the activity referred to contributes to a superfluous or extrinsic type of motivation; however, the data are not consistent with that.

There is a distinction with Raineri (2017) about indirect effects; that author detected that compensation significantly affects performance through human capital and that the mediate effect is with affective commitment, but there is no significant causality through human capital.

It can be deduced that the orientation of these activities in Chile is different from what it is in this country; interpreting that in Chile, salary payments, incentives and benefits are carried out to provide greater economic support; this may lead to extrinsic motivation.

The coincidence between both studies is that no immediate causality has been found between compensation and incentives and performance. For this activity to affect performance, it must do so through affective commitment or human capital.

Los The statistics shown in Table 9, referring to $\mathrm{H}_{3}$ and alluding to empowerment practices, are significant and show causalities through affective commitment and human capital. The total effect analyzed for this subdimension is represented by the highest coefficient of determination (shown in Annex B), considering, as a reference, the causalities with other activities.

Among the mediated effects, the greatest is that of affective commitment; implying that empowerment contributes to people recognizing the appreciation given to them in companies and work teams and thus forming favorable concepts of these.

Empowerment activities also affect performance through human capital; there is a possibility of learning by involving the person closely with the work and related decisions. These activities are oriented to improve the emotional involvement; however, this does not exclude that they can affect in other ways (Raineri, 2017).

There is similarity between the data obtained with this work and the Raineri (2017); the discrepancy is with the $\beta$ values, considered mediations (those of this study are lower than those of the cited author); however, when analyzing the difference between the $\beta$ coefficient of the mediation of affective commitment and the value of the indirect effect with human capital, in each of the investigations, the differences between the mediated effects of both studies are close to each other.

HPWS directly affect performance more than through human capital, considering the values in Table 10; the latter effect indicated, although not of the same extent as the former, is nevertheless noteworthy. Considering the sub-dimensions, compensation and incentive activities and empowerment are the ones with significant indirect causality.

The generic analysis is complemented by the specific results. There are 2 activities that support causality through affective commitment: training and performance appraisals and coaching. Although these effects are not significant in the analysis of the variable (HPWS), they are still relevant when analyzed separately.

The difference between the values of this study with those of Raineri (2017) is understood, considering that this study has been done in one type of company and with people with similar roles (homogeneity), while the cited author has gone to companies of various types and with people with different jobs (heterogeneity). In addition, there is an important difference in the number of the population.

How the human talent activities of companies are carried out varies from one business to another. Another relevant aspect is the orientation of the activities, as explained by Raineri (2017). The human 
talent area may evaluate the performance of a person with the intention of improving their capabilities; other times they may do so to know how to compensate the person, linking this approach to the engagement.

Takeuchi et al. (2007) found similar causality; the difference is that the authors performed a (different) hierarchical regression analysis to support their thesis. Another divergent aspect is that they have included simulated variables (dummies).

There are also noteworthy differences in the instruments; for example, the questionnaires on HPWS by Takeuchi et al. (2007) did not include statements on job description or empowerment practices. Another difference of the authors is that they took social exchange in the company as a mediating variable instead of affective commitment.

There are two ways to affect performance: through skills (human capital) or through motivation. The "motivational" path can be explained by more than one variable. Raineri (2017) proposed affective commitment as a mediator of the type; and Takeuchi et al. (2007), social exchange.

Important guidelines are also Fey et al. (2009) and Jiang et al. (2012). The first authors addressed 5 human talent practices, considering each one as a variable; and control variables such as country, size and time of the firm; in addition to working with the partial least squares method.

Jiang et al. (2012) did structural equation analysis and worked out a different structure mediation, with "financial performance" being the dependent variable, while two more mediators are considered: resignation rate and "operational performance", which depend on capabilities and "motivational path"

Qiao et al. (2009) are also redeemable; they vary by statistical analyses and contemplation of control variables (e.g., gender and marital status). Their objective was to find correlations between HPWS and "organizational commitment". Although they did not find significant mediation in affective commitment, the specific results allow us to understand that commitment is associated with causalities between certain human talent activities and performance.

Theoretical research that also supports are van Knippenberg (2000) with Boxall and Macky (2009). The former points out that "organizational identification" is linked to motivation and performance.

The second study makes it possible to distinguish motivational improvement activities from opportunity improvement activities. Those of the first type contribute to improve people's perceptions of their jobs; this leads to being constant with the company or the team; this group of activities are "high commitment management" or "high commitment work strategies"; the activities of the second type counteract the centralization of company decisions; that is, in these actions people are involved in company decisions; and their independence is encouraged, considering the real experience of situations with proposals consistent with them; this counteracts certain company restrictions.

Variables that are suggested in causal studies linked to this model are the social, economic, legal, and other characteristics and circumstances of the country of the company where the research is carried out; one can also consider the origin of the business, time, size, number of workers, its market share, etc.; Raineri (2017) supports this.

To carry out more precise studies on these variables, it is relevant to recognize which are the most relevant activities by the human talent areas of the companies (Boxall and Macky, 2009); in addition to understanding what the concepts of these activities by these areas are (which may 
be different from what is postulated in theory), as well as to know the purpose or orientation of each activity. It is also important to know what are the effects of the human talent activities that people in the company can distinguish.

It is possible that what is mentioned in the previous paragraph may be a support to classify human talent activities in a more precise way. This would lead to a clearer picture of the reality when making the respective analyses.

\section{References}

Aiken, L. (1980). Content Validity and Reliability of Single Items or Questionnaires [Validez de Contenido y Confiabilidad de Enunciados Individuales o Cuestionarios]. Educational and Psychological Measurement, 40, 955-959. doi: 10.1177/001316448004000419

Aiken, L. (1985). Three coefficients for analyzing the reliability and validity of ratings [Tres coeficientes para analizar la confiabilidad y validez de puntajes]. Educational and Psychological Measurement, 45, 131-142. doi: 10.1177/0013164485451012

Allen, N., \& Meyer, J. (1990). The measurement and antecedents of affective, continuance and normative commitment to the organization [La medida y los antecedentes del compromiso afectivo, de continuidad y normative para con la organización]. Journal of Occupational Psychology, 63, 1-18. doi:10.1111/j.2044-8325.1990.tb00506.x

Boxall, P., \& Macky, K. (2009). Research and theory on high-performance work systems: progressing the high-involvement stream [Investigación y teoría sobre los sistemas de trabajo de alto rendimiento: progresando con la corriente del alto involucramiento]. Human Resource Management Journal, 19(1), 3-23. doi: 10.1111/j.17488583.2008.00082.x

Buchanan, B. (1974). Building Organizational Commitment: The Socialization of Managers in Work Organizations [Construyendo Compromiso Organizacional: La Socialización de Gestores en Organizaciones de Trabajo]. Administrative Science Quarterly, 19(4), 533. doi:10.2307/2391809

Chin, W. (1998). Commentary: Issues and Opinion on Structural Equation Modeling.

MIS Quarterly, 22(1), vii-xvi. Recuperado de https://www.jstor.org/stable/249674

Chow, I. (2004). An Empirical Investigation of Coherent Human Resource Practices and High Performance Work Systems [Una Investigación Empírica de Prácticas Coherentes de Recursos Humanos y Sistemas de Trabajo de Alto Rendimiento]. International Journal of Employment Studies, 12(1), $125 . \quad$ Recuperado de https://search.ebscohost.com/login.aspx?direct=true\&db=bth\&AN=22697325\&lang=es\& site=ehost-live

Combs, J., Liu, Y., Hall, A., \& Ketchen, D. (2006). How much do high-performance work practices matter? A meta-analysis of their effects on organizational performance [¿Cuánto importan las practices de trabajo de alto rendimiento? Un metanálisis de sus efectos en el desempeño organizacional]. Personnel Psychology, 59(3), 501-528. doi:10.1111/j.17446570.2006.00045.x 
Corbetta, P. (2007). Metodología y técnicas de investigación social. Madrid, España: McGrawHill / Interamericana de España, S. A. U.

Defilippi, G., Gálvez, M., \& Velarde, J. (2017). Prácticas de mejora de gestión del desempeño: estudio de casos en tres empresas peruanas del sector privado (tesis de maestría). Recuperado del Repositorio Institucional de la Universidad ESAN. (URI http://repositorio.esan.edu.pe/handle/ESAN/1078)

Delaney, J., \& Huselid, M. (1996). The impact of Human Resource Management on Perceptions Organizational Performance [El impacto de la Gestión de Recursos Humanos en las Percepciones del Desempeño Organizacional]. Academy of Management Journal, 39(4), 949-969. doi:10.2307/256718

Dess, G. G., \& Robinson, R. B. (1984). Measuring organizational performance in the absence of objective measures: The case of the privately-held firm and conglomerate business unit [Midiendo el desempeño organizacional en ausencia de medidas objetivas: El caso de la empresa privada y la unidad de negocios del conglomerado]. Strategic Management Journal, 5(3), 265-273. doi:10.1002/smj.4250050306

Fey, C., Morgulis-Yakushev, S., Park, H. J., \& Björkman, I. (2009). Opening the black box of the relationship between HRM practices and firm performance: A comparison of MNE subsidiaries in the USA, Finland, and Russia [Abriendo la caja negra de la relación entre las practices de GRH y el desempeño de la empresa: Una comparación de subsidiarias de empresas multinacionales - EMM - en los EUA, Finlandia y Rusia]. Journal of International Business Studies, 40, 690-712. doi:10.1057/jibs.2008.83

Fincham, J. (2008). Response Rates and Responsiveness for Surveys, Standards, and the Journal [Tasas de Respuesta y Sensibilidad para Encuestas, Reglas y la Revista]. American Journal of Pharmaceutical Education, 72(2), 1-3. doi: 10.5688/aj720243

Hayes, A. (2013a). Introduction to mediation, moderation, and conditional process analysis : a regression-based approach [Introducción al análisis de mediación, moderación y proceso condicional: un enfoque basado en la regresión]. Nueva York, Estados Unidos: Guilford Publications, Inc.

Hayes, A. (2013b). PROCESS procedure for SPSS Release (2.16.3) [Macroinstrucción de computadora].

Huselid, M. (1995). The impact of human resource management on turnover, productivity, and corporate performance [El impacto de la gestión de recursos humanos en la rotación, productividad y el desempeño corporativo]. Academy of Management Journal. 38. 635672.

Recuperado http://www.markhuselid.com/pdfs/articles/1995_AMJ_HPWS_Paper.pdf

Ilies, L., \& Metz, D. (2017). The Link Between Organizational Culture and Organizational Performance - A Literature Review [El Enlace entre la Cultura Organizacional y el Desempeño Organizacional - Una revision de literatura]. Managerial Challenges of the Contemporary Society, 10(1), 1-10. Recuperado de https://search.proquest.com/docview/2014396637/fulltextPDF

Jiang, K., Lepak, D., Hu, J., \& Baer, J. (2012). How Does Human Resource Management Influence Organizational Outcomes? A Meta-Analytic Investigation of Mediating Mechanisms [¿Cómo la Gestión de Recursos Humanos Influencia a los Resultados Organizacionales? Una 
Ludeña Jugo, A.D. and Arbulú Ballesteros, M.A. (2021) High Performance Work Systems and Organizational Performance of Sales Representatives of Pharmaceutical Companies in Chiclayo Vol.13(2): 51-71

Investigación Metaanalítica de Mecanismos Mediadores]. Academy of Management Journal, 55(6), 1264-1294. doi: 10.5465/amj.2011.0088

Kallner, A. (2018). Laboratory Statistics ( $2^{\mathrm{a}}$ ed.). Ámsterdam, Países Bajos: Elsevier Inc. doi: 10.1016/C2017-0-00959-X

van Knippenberg, D. (2000). Work Motivation and Performance: A Social Identity Perspective [Motivación de Trabajo y Desempeño: Una Perspectiva de Identidad Social]. Applied Psychology: An International Review, 49(3), 357-371. doi: 10.1111/1464-0597.00020

Lepak, D., Liao, H., Chung, Y., \& Harden, E. (2006). A Conceptual Review of Human Resource Management Systems in Strategic Human Resource Management Research [Una revision conceptual de los Sistemas de Gestión de Recursos Humanos en la Investigación de la Gestión Estratégica de Recursos Humanos]. Research in Personnel and Human Resources Management, 25(06), 233. doi:10.1016/S0742-7301(06)25006-0

Mathis, R., \& Jackson, J. (2008). Human Resource Management [Gestión de Recursos Humanos] (12th ed.). Mason, Ohio, Estados Unidos: Thomson South-Western. Recuperado de https://core.ac.uk/download/pdf/33797590.pdf

Meyer, J., \& Allen, N. (1984). Testing the "side-bet theory" of organizational commitment: Some methodological considerations [Probando la "teoría de apuesta secundaria" del compromiso organizacional: Algunas consideracional metodológicas]. Journal of Applied Psychology, 69(3), 372-378. doi:10.1037/0021-9010.69.3.372

Muntean, S. (2014). Talent management and its contributions to the performance of the multinational organizations [Gestión del talento y sus contribuciones al desempeño de las organizaciones multinacionales]. Revista Academiei Fortelor Terestre, 19(3), 300-306. Recuperado de http://www.doctorateposdru.ulbsibiu.ro/media/phd/file_31b_bdi_journal_full_article_000371.pdf

Noel, G., Frías, M., \& Silva, J. (2019). Propuesta de un sistema de evaluacion ${ }^{1}$ de desempeño en una empresa constructora. (trabajo de investigación). Recuperado del Repositorio Institucional de la UP. (URI http://hdl.handle.net/11354/2311)

Pardo, M., \& Ruiz, M. (2005). Análisis de datos con SPSS 13 Base. Madrid, España: McGraw-Hill.

Qiao, K., Khilji, S., \& Wang, X. (2009). High-performance work systems, organizational commitment, and the role of demographic features in the People's Republic of China [Sistemas de trabajo del alto rendimiento, compromiso organizacional, y el rol de las características demográficas en la República Popular de China]. The International Journal of Human Resource Management, 20(11), 2311-2330. doi: 10.1080/09585190903239682

Raineri, A. (2017). Linking human resources practices with performance: the simultaneous mediation of collective affective commitment and human capital [Vinculando las prácticas de recursos humanos con el desempeño: la mediación simultánea del compromiso afectivo colectivo y el capital humano]. International Journal of Human Resource Management, 28(22), 3149-3178. doi:10.1080/09585192.2016.1155163

Schultz, T. W. (1961). Investment in human capital [Inversión en capital humano]. The American Economic Review, LI(1), 1-17. Recuperado de http://la.utexas.edu/users/hcleaver/330T/350kPEESchultzInvestmentHumanCapital.pdf

Subramaniam, M., \& Youndt, M. A. (2005). The Influence of Intellectual Capital on the Types of Innovative Capabilities [La Influencia del Capital Intelectual en los Tipos de Capacidades 
Innovadoras]. Academy of Management Journal, 48(3), 450-463. doi:10.5465/amj.2005.17407911

Sun, L. Y., Aryee, S., \& Law, K. S. (2007). High-performance human resource practices, citizenship behavior, and organizational performance: A relational perspective [Prácticas de recursos humanos de alto rendimiento, comportamiento de ciudadanía, y desempeño organizacional: una perspectiva relacional]. Academy of Management Journal, 50(3), 558577. doi:10.5465/amj.2007.25525821

Takeuchi, R., Lepak, D. P., Wang, H., \& Takeuchi, K. (2007). An Empirical Examination of the Mechanisms Mediating Between High-Performance Work Systems and the Performance of Japanese Organizations [Una Examinación Empírica de los mecanismos mediadores entre los Sistemas de Trabajo de Alto Rendimiento y el Desempeño de organizaciones japonesas]. Journal of Applied Psychology, 92(4), 1069-1083. doi:10.1037/00219010.92.4.1069

Wright, P. M., Gardner, T. M., \& Moynihan, L. M. (2003). The impact of HR practices on the performance of business units [El impacto de prácticas de RRHH en el desempeño de unidades de negocios]. Human Resource Management Journal, 13(3), 21-36. doi:10.1111/j.1748-8583.2003.tb00096.x 


\section{Annexes}

Annex A

Questionaries

Annex A1

Questionnaire about perceptions of high-performance work systems (HPWS) by people involved with company work teams.

Selection of persons

1.It takes a lot of effort to select the right person.

2.Emphasis is placed on the long-term potential of the individual during the selection process.

3.Applicants attend structured interviews (job-related questions, same questions for all applicants) before being hired.

4.Applicants give formal examinations (written or work samples) before being hired.

Performance evaluation and training

5. Extensive training programs are offered to people in those skills that are most indispensable to their jobs.

6. Formal training programs are in place to teach new hires the skills they need to do their jobs.

7.People in this job typically attend training programs every few years.

8. Formal training programs are offered to increase people's chances for promotion.

9. The performance of people in this job is evaluated on a regular basis (at least once a year).

10. The evaluation of people's performance is based on objective and measurable results.

11. People evaluations emphasize long-term development.

Description of the work

12. The duties of this job are clearly defined. 
13. This job has a current job description.

Compensations and incentives

14. Individuals receive incentives based on the company's profits.

15. Salary increases for this position are based on job performance.

16. Individuals have the possibility of earning individual incentives or commissions for productivity or other individual performance results.

17. Individuals receive commissions for individual performance.

18. Individuals receive commissions for group performance.

Annex A2

Questionnaire about the perceptions of affective commitment by people involved with work teams in companies

1.I have a strong sense of identification with this company.

2.I enjoy telling my friends that working with this organization is great.

3.I am proud to say that I am part of this organization.

4.This organization has a strong personal meaning to me.

Annex A3

Questionnaire about the perceptions of human capital of those involved in company work teams.

1.People's abilities to carry out their work.

2. The knowledge of the people to carry out their work.

Annex A4

Questionnaire about perceived organizational performance of those involved in company work teams. 
1.The quality of our products, services, or programs.

2.The development of new products, services, or programs.

3.The satisfaction of our customers and internal users.

4.The satisfaction of our external customers and users.

5.The productivity of the team.

6. The quality of treatment between the people in charge and the people.

\section{Annex B}

Coefficients of determination for total effects

\begin{tabular}{|c|c|}
\hline Effects & $R^{2} \mathrm{~S}$ \\
\hline of the selection of people & ,034 $4^{\text {n.s. }}$ \\
\hline of training and performance evaluations & , $119^{\text {n.s. }}$ \\
\hline of job descriptions & ,204 \\
\hline of the group or dimension of skills improvement activities & $144^{\text {n.s. }}$ \\
\hline $\begin{array}{l}\text { of compensation and incentives, type of motivational } \\
\text { enhancement, empowerment practices, classification of } \\
\text { opportunity }\end{array}$ & ,232 \\
\hline $\begin{array}{l}\text { of empowerment practices, of the classification of } \\
\text { opportunity enhancement practices }\end{array}$ & ,238 \\
\hline of HPWS & 289 \\
\hline
\end{tabular}

Note: ${ }^{\text {n.s.: }}$ the value does not represent 